\title{
Effect of Application of Physics Learning material Using Multimode representation to Improve Problem Solving Ability
}

\author{
Merta Simbolon ${ }^{1}$ \\ Physics Education, School of Postgraduate Studies \\ Indonesia University of Education, \\ Bandung, West Java, Indonesia \\ $\underline{\text { mertasimbolon@gmail.com }}$
}

\author{
Parlindungan Sinaga ${ }^{2}$ \\ Physics Education Department \\ Indonesia University of Education \\ Bandung, West Java, Indonesia
}

\author{
Setiya Utari ${ }^{3}$ \\ Physics Education Department \\ Indonesia University of Education, \\ Bandung, West Java, Indonesia
}

\begin{abstract}
The purpose of this study was to determine the effect of applying physics learning materials use multimode representation to enhance the problem solving. Samples in this study were students of class $X$ one high school in Bandung with the number of 69 students who were divided into experimental class and control class. Experimental class taught using learning materials developed by the researchers while the control class taught using books at school. The sampling technique is a technique carried out random class. The research instrument used is the problem-solving ability test on the material temperature and heat. Stages of problem solving is based on Rosengrant problem-solving strategies consisting of four stages: translating the question asked; simplify the problem; describe his physical form; and describes the mathematical form. The results showed that the $\mathrm{N}$-Gain significance value smaller than $\alpha(0.000$ $<0.05)$ so that $\mathrm{HO}$ and conclude that the use multimodus physics learning material representations can more significantly improve students' problem-solving abilities.
\end{abstract}

Keywords-learning materials; problem-solving ability; multimode representation; problem solving strategies

\section{INTRODUCTION}

Learning physics as one branch of science can become a vehicle for students to learn about themselves and the environment, as well as prospects for further development in applying it in our daily lives. This learning process emphasizes providing direct experience to develop competencies in order to understand the nature around scientifically. Chingos said that many factors affect the learning process of students. Student learning primarily occurs through interaction with others (teachers and friends) as well as the learning material [1]. The main purpose of the learning material is to facilitate effective teaching, increase knowledge, skills and abilities of students to monitor the level of assimilation of information, and to contribute to the overall development of students in education. Therefore, teachers need to select or improvise in the learning material appropriate to facilitate effective teaching and learning process and motivate learners [2].

Importance of learning materials has been investigated by several researchers. Eniayeju describes the learning material as a material that provides a real experience for students who want to improve intellectual [3]. Furthermore, Ige states that the learning material makes the learning process easier to understand and more real [4]. Other researchers also revealed the importance of learning materials in the learning process of students that [5],[6], [7],[8],[9],[10], and [11]. Learning materials become an important means used by students during the learning process and as a learning resource that is very important, learning materials are expected to meet student needs to broaden and achieve meaningful learning.

Findings Kesidau \& Roseman stated their criticism indicating that the materials in the learning materials that are widely used include topic-level low, only focuses on the techniques of vocabulary, failed to consider the main priority students about science, the less will be the explanation of science related real world events, and gives students little opportunity to develop an explanation of an incident [12]. Another problem found that the material received by students during the learning is often only in the form of concepts without knowing its usefulness in solving physics phenomena whereas many physical phenomena that is very close to the daily lives of students.

Interviews conducted by researchers of the teachers and students at one high school in Bandung found that the characteristics of the expected student learning material is a learning material that contains phenomena and daily problems in physics. Students look forward to also understand the 
application of learning physics at school. But the reality is based on an analysis of the physics learning material used at the school, learning material-oriented only cognitive planting so that the students only know the concept but not be able to use the concepts in solving physics problems.

Therefore, the required learning materials are developed and designed so that students not only mastered the concept but also has the ability to problem-solving (problem solving) because problem solving skills considered essential in science learning in particular physics. It is written in the [13] that the level of SMA / MA, physics is considered essential to be taught as a separate subject to several considerations. First, in addition to providing supplies to students of science, physics was intended as a vehicle to foster thinking skills that are useful to solve problems in everyday life. Second, subjects need to be taught physics for specific objective is to equip students the knowledge, understanding and a number of capabilities required to enter higher education and develop science and technology.

In the study of physics, [14] states that the best way to help students to learn is by bringing them face to face with the object or phenomenon in the concept being studied. When an object in real life is not possible, then the alternative for teachers is to use the representation. Representations must be integrated together called multimode representation because the student has the ability varying in understanding the concepts so that when students are not able to understand the concept well with the representation of the students will be helped by the other representation [15].

Research on the problem-solving abilities have been done. Several previous studies such as [16] and [17] still uses a variety of learning models to improve students' problemsolving abilities and no one has been developed using the learning material-oriented problem-solving abilities. Learning materials become a major source of learning for students and as a means of self-learning at home so it is important to be developed according to the needs of students, in this case to enhance the problem solving. Learning materials developed using multimode representation to meet the abilities of students vary in understanding the concepts and make learning not only understand its mathematical physics course but physical meaning in it.

\section{RESEARCH METHOD}

This study was conducted in one high school in the city of Bandung. In this study, students in the experimental class taught using learning materials multimode representation while the control classes was taught using books that usually used in school. This study uses a quasi-experimental research design randomized control group pretest-posttest design. The sampling technique is random technique classes conducted with a sample of 69 students of class X from one high school in Bandung. Data was collected using test instruments problem-solving ability as much as 8 question and each problem solved by using problem solving strategies Rosengrant stages. There were four stages, translating the question asked; simplify the problem; describe his physical form; and describes the mathematical form.

\section{RESULTS AND DISCUSSION}

Problem solving ability of students regarding the material and heat temperature is measured with a test description about the number 8 . Improved problem solving skills of learners in this study is the average value of the initial test (pretest) and final test (post-test) in the assessment scale from 0 to 100 . The data obtained in the pretests (pretest), final test (post-test) and calculation N-Gain problem solving ability of students in the experimental class and control class is presented in Table 1.

TABle I. The Result Test of Problem Solving Ability Students

\begin{tabular}{|l|c|c|c|c|c|c|}
\hline \multirow{2}{*}{} & \multicolumn{3}{|c|}{ Experiment Class } & \multicolumn{3}{c|}{ Control Class } \\
\cline { 2 - 7 } & $\begin{array}{c}\text { Pre- } \\
\text { test }\end{array}$ & $\begin{array}{c}\text { Post- } \\
\text { test }\end{array}$ & $\begin{array}{c}\text { N- } \\
\text { Gain }\end{array}$ & $\begin{array}{c}\text { Pre- } \\
\text { test }\end{array}$ & $\begin{array}{c}\text { Post- } \\
\text { test }\end{array}$ & $\begin{array}{c}\text { N- } \\
\text { Gain }\end{array}$ \\
\hline $\begin{array}{l}\text { Number of } \\
\text { students }\end{array}$ & 33 & 33 & 33 & 36 & 36 & 36 \\
\hline Average & 57,45 & 87,52 & 71 & 48,99 & 63,98 & 30 \\
\hline
\end{tabular}

Table 1 shows that the average test scores of students pretest in problem-solving abilities for the experimental class and control class amounted to 57.45 at 48.99. As for the difference in pretest results experimental class of 9.46 is higher than the control class. The students then do the test again after the learning has been completed. From the average value of the test problem solving ability of students in the final test for the experimental class and control class amounted to 87.50 at 63.98 . As for the difference in the prestest results of the experimental class 24.52 is higher than the control class. The findings obtained from the calculation N-Gainfor the experimental class was 0.71 while the control class is 0.29 . Based on the categorization of [18], the result of an increase for the experimental class in the high category and the control class with category. These findings indicate that the value of problem-solving abilities in the experimental class after learning performed better results compared with the control class. Diagram average percentage score pretest, posttest and $\mathrm{N}$-Gain problem solving ability at the temperature and heat the material in the experimental class and control class is presented in Figure 1.

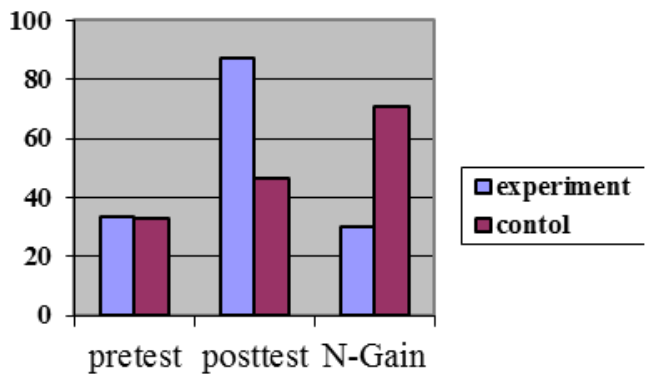

Fig. 1. Chart Comparison Average Score pretest, posttest and N-Gain

Based on the results obtained that the data pretest, posttest, and N-Gainproblem solving ability of students in normal distribution and homogeneous, then the next step testing the hypothesis about an increase in students' problem solving ability by means of parametric test (t-test). The purpose of this $\mathrm{t}$-test is to see the difference in the average score improvement of students' problem-solving abilities between the 
experimental class and control class. The test results with the t-test are presented in Table 2 .

TABLE II. TeSt OF Problem Solving SKiLl on the ExPERIMENT AND CONTROL GROUP

\begin{tabular}{|c|c|c|c|l|}
\hline Data & Class & N & Sig* & Conclusion \\
\hline \multirow{3}{*}{ Pretest } & Eksperimen & 33 & \multirow{2}{*}{0,085} & No difference \\
\cline { 2 - 3 } & Kontrol & 36 & & \\
\hline \multirow{2}{*}{ Posttest } & Eksperimen & 33 & \multirow{2}{*}{0,000} & $\begin{array}{l}\text { There } \\
\text { Differences }\end{array}$ \\
\cline { 2 - 3 } & Kontrol & 36 & & Nonn \\
\hline
\end{tabular}

Table 2 shows that the significant value on the pretest of 0,085 . The significance value greater than the value $\alpha(0.085>$ 0.05) then it is concluded that there is no difference in the ability early on problem-solving abilities between the experimental class and control class. At posttest, the significance value of 0.000 . The significance value less than the value $\alpha(0.00<0.05)$ then it is concluded that there are differences between the problem solving abilities experimental class and control class. In the next step, the calculated value of significance $\mathrm{N}-\mathrm{Gain}$ and the result of 0.00 . The significance value less than the value $\alpha(0.00<0.05) \mathrm{H} 0$ is accepted and drawn the conclusion that the application of the use of learning physics learning material multimode representation could significantly improve the problem solving ability of students compared with the implementation of learning physics using learning material regular at school.

The cause of the effect of the application of physics learning material developed using multimode representation writer in improving students' problem solving ability is the presentation of the contextual problems and close to student life so that a problem given was simple and easy to understand.

In this learning material also trained stages in problem solving strategies Rosengrant sequentially and systematically. Their exercise in problem solving through various examples of questions will greatly assist students in getting used to solve the physics are correct and meaningful, not just a mathematical settlement but also to understand the meaning of his physical. Students' ability to solve the problems of physics considered important in accordance with the statement of [19] that learning science applicative oriented, developing the ability to think, curiosity, as well as the establishment of a caring and responsible attitude towards the natural and social environment. Applicative oriented in the sense that students are given the opportunity to apply their knowledge in solving the problems faced in everyday life.

The use multimode representation in the stages of problem solving also greatly assist students in understanding and problem-solving abilities. Successful problem solving process depends on the skill in representing issues such as constructing the representation in words, charts, tables, and equations, completion, and the manipulation of symbols [20].

\section{CONCLUSION}

The test results of problem-solving ability concluded that it is better in the learning process of students socialized and trained to solve problems systematically and not just focused on the completion mathematically course that physics concepts more meaningful for students and can be used in their daily life. Learning material becomes an important thing of student learning so it should be developed in accordance with the needs of students.

\section{Acknowledgment}

I want to say thank you to Parlindungan Sinaga and Setiya Utari for their guidance of writing this article.

\section{References}

[1] Chingos, M. M dan Whitehurst, G. J. (2012). "Choosing Blindly Instructional Materials, Teacher Effectiveness, And The Common Core": Brown Centre

[2] Megbo, (2015). "Evaluation of Modern Development in Teaching and Learning Process through Instructional Materials Utilization. International Journal of Multidisciplinary Research and Development".Volume: 2, Issue: 9

[3] Eniayeju, I. E. (2005). "Improvisation of Effective Learning of Physics": The Asaba Education Technical and Science Education Journal, 1 (1), 92-93

[4] Ige, I. O., Arop, B. A. \& Ibe, J. O. (2000). "Problems of Improvising Instructional Materials for the Teaching and Learning of Chemistry". STAN Annual Conference

[5] Amodu, (2014). "Towards Effective Teaching of Physics Through the Use of Relevant Instructional Materials". International Journal Of Multidisciplinary Sciences And Engineering, Vol. 5, No. 3

[6] Utibe, (2015). "Problems Of Improvising Instructional Materials For The Teaching And Learning Of Physics In Akwa Ibom State Secondary Schools, Nigeria". British Journal of Education Vol.3, No.3

[7] Kollofel, B. (2012). "Exploring The Relation Between VisualizerVerbalizer Cognitive Styles And Performance With Visual Or Verbal Learning Material. Elsevier, Computer and Education".

[8] Emmanuel. (2015). "Influence of Improvisedteaching Instructional Materials on Chemistry Students' Performance in Senior Secondary Schools in Vandeikya Local Government Area of Benue State, Nigeria".International Research in Education Vol. 3, No. 1

[9] Oladejo, M. A., Olosunde, G. R., Ojebisi, A. O. \& Isola, O. M. (2011). "Instructional Materials and Student Academic Achievement in Physics, Some Policy Implications". European Journalof Humanities and Social Science, 2(1), 187-190

[10] Aina. (2013). "Instructional Materials and Improvisation in Physics Class: Implications for Teaching and Learning". IOSR Journal of Research \& Method in Education (IOSR-JRME). Volume 2, Issue 5

[11] Mboto, F. A., Ndem, N. U. \& Stephen, U. (2011). "Effects of Improvised materials on Student's Achievement and Retention of the Concept of Radioactivity”. African ResearchReview, An International Multi-Disciplinary Journal, Ethiopia, 5(1), 342-348

[12] Kesidou, S., \& Roseman, J. E. (2002). "How well do middle schoo science programs measure up? Findings from Project 2061's curriculum review". Journal of Research in Science Teaching, 39(6)

[13] Ministerial Regulation No. 22 of 2006 on the Content Standards for Primary and Secondary Education Unit.. Bandung

[14] Omosewo, I.A. (1980). "Vocational Education in Nigeria, Lagos". Longman Publication

[15] Sinaga, et all. (2014). "Improving the Ability of Writing Teaching Materials and Self-Regulation of Pre-Service Physics Teachers through Representational Approac".International Journal of Sciences: Basic and Applied Research (IJSBAR)

[16] Henny. (2014). "Application of Generative Learning Strategies to Improve Comprehension Problem Solving Concepts and Problem Solving Ability High School Students on Fluid Material Static". IPA Education Graduate Thesis UPI 
[17] Ilyas, (2007). "Inquiry Based Learning Model to Improve Understanding of Concepts and Capabilities Troubleshooting Electrical Concepts dynamic". IPA Education Graduate Thesis UPI

[18] Hake, R.R. (1998). Interactive-engagement vs traditional method: A sixthousand students survey of mechanic test data for introductory physics course. American Journal of Physics, 66, 64-74

[19] Ministry of National Education. (2012). Jakarta

[20] Amit, M \&Fried, M.N. (2005). "Multiple Representations in 8th Garde Algebra Lesson":Are Learners Getting in. Proceedings of the 29th Conference of International Group for the Psychology of Mathematic Education 